OPEN ACCESS

Manuscript ID:

EDU-2021-09033861

Volume: 9

Issue: 3

Month: June

Year: 2021

P-ISSN: 2320-2653

E-ISSN: 2582-1334

Received: 24.03.2021

Accepted: 05.05.2021

Published: 01.06.2021

Citation:

Ozdemir, Furkan.

"Investigation of Teachers'

Opinions About Open

Course Educational

Materials: Case of Turkey."

Shanlax International

Journal of Education,

vol. 9, no. 3, 2021,

pp. 84-90.

DOI:

https://doi.org/10.34293/

education.v9i3.3861

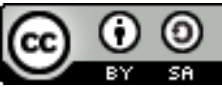

This work is licensed under a Creative Commons Attribution-ShareAlike 4.0 International License

\section{Investigation of Teachers' Opinions about Open Course Educational Materials: Case of Turkey}

\author{
Furkan Ozdemir \\ Research Assistant, Department of Mathematics Education, Siirt University, Siirt, Turkey \\ https://orcid.org/0000-0001-9116-1480
}

\begin{abstract}
The aim of this study is to determine whether math teachers have an idea about the open course materials and to get their opinions about the use of open course materials. The study employs a qualitative research approach. The research is carried out on 12 math teachers with professional experience working at all two high schools in the Eastern Anatolia Region in Turkey. In the research, Open Course Materials Interview Form (OCMIF) developed by the researchers was applied as a data collection tool. The content analysis method is used for data analysis. According to the results, it was seen that the teachers had information about the open course materials. Teachers also expressed the opinion that those not insufficient and uncontrolled for such sharing would be unhelpful. In addition, the teachers stated that there are some situations in which open lesson materials are not used in our country. In addition, pre-course preparation and post-course evaluation, the smart board for documents and topics related to the use of video, presentation, animation, such as to benefit from the activities were used.
\end{abstract}

Keywords: Open course, Distance education, Math teachers, Materials, Qualitative research

\section{Introduction}

These days, when the coronavirus epidemic affects the whole world, online education is used extensively. One of the most important resources of online education is documents that are open to everyone or private use. One of these is open course materials. Open course materials are frequently used, especially in mathematics lessons. Open Courses are free and open educational resources for faculty, students and self-learners around the world. (TUBA, 2011). The University Open Course Materials (OCM) is an open-source course for all courses offered in a university. Open course material covering one semester (14 weeks or 42-50 hours) lecture notes, lecture notes, lectures (PowerPoint presentations, video, animation, etc.), sample exams and solutions, sample homework and solutions, projects and applications, additional reading parts (TUBA, 2011). Open course materials can also be used to develop open-source materials to produce more professional resources. Each individual can take the courses by using the open course materials. Those who adopt lifelong learning can contribute to their education which can be trained according to their interests. Each instructor prepares the open lecture materials voluntarily for the benefit of humanity. OpenCourseWare (OCW) within system of higher education will enrich resources of students about the course. At the same time, it will enable the faculty members to compare the contents of the courses they teach with similar lecturers, to benefit from them and to improve them. In addition, there is the potential of open lecture materials that anyone who wants to improve themselves can create an important resource for lifelong learning (Yazıc1, et al., 2008). Open course materials are a way to e-learning. With sharing of course contents in an electronic environment, getting an education is changing. 


\section{Open Course in the World}

In 1999, it first lectured at the Massachusetts Institute of Technology (MIT) on lecture notes, audio and video recordings, etc. Over time, these studies have begun to spread to other countries around the world. In 2002 The Massachusetts Institute of Technology (MIT), which was accepted as one of the most prestigious universities globally, launched the OpenCourseWare (OCW) project, eliminating an important barrier for the masses to reach the information. (Johansen ve Wiley, 2010). With the establishment of the International OpenCourseWare Consortium (OCW), it is aimed to gather the universities that support the open lesson in the world under a single roof. The purpose of the consortium is to take education as a whole. For this reason, the name Open Education has been. The education as a whole is not intended to address individual courses.

An individual can watch the video recordings of the courses you want to receive from MIT and use them offline in places where there is no internet access available. This allows following the lessons regularly. Not only do you follow the courses you take, but you also reinforce the subjects learned with the homework assignments, and even take the exams of the course and receive a certificate of participation when the course period ends. MIT's open course materials project, which started with 50 courses, has reached 2100 courses today and usage statistics show that every month an average of one million visitors enter the site. (MIT, 2012). The Year of Open (2017) focused on open topics globally, included 85 global experts from over 140 countries. Over 8,700 users participated in Open Education Week in over 20 languages, and OE Global Conference in Cape Town had attendees and presenters from over 48 countries (OEC, 2018).

\section{Open Course in Turkey}

Open Course Ware project of the Academy of Sciences of Turkey to implement (TUBA) pioneered the Open CourseWare Consortium is planned to be established. Necessary studies have been carried out on this subject. A protocol has been signed between 34 universities, Higher Education Council and TUBA and National Open Course Materials Consortium (UADM) have been established. The most important purpose of the UADM is to carry out the necessary studies to realize the Open Course Materials Project (Özkul, 2008). The first meeting was held in 2007 with the participation of several universities. Few universities have been able to achieve this. To eliminate the language problem, translation was planned and supported by academics (Eker, 2015). The project was further developed by the State Planning Organization (SPO), providing financial assistance. Research in all areas of science in Turkey, to promote science and research and to honor the humanity of those who contributed in these areas; directing young people to science and research; Turkey had to raise the social status of scientists and researchers, and work to protect; Ministry of Industry and related science and technology to help raise the standard of research, legal personality, scientific, administrative and financial autonomy, special budgets Turkey Academy of Sciences (TUBA short name) was established. TUBA organizes projects and workshops to promote the development of Open Course Materials (Al \& Madran, 2013).

The aim of this study is to determine whether teachers have an idea about the open course materials and to get their opinions about the use of open course materials. This study, it is aimed to make the teachers to be informed about the open lesson materials and to contribute to sharing the courses on the internet. The study is very important as it tries to raise awareness about the increasingly common course materials in the world. In the literature, no studies were conducted to obtain the opinions of the teachers. It is thought that the contribution to literature will be high. This situation increases the importance of the study.

\section{Method \\ Research Model}

The study employs a qualitative research approach. The case study design is accepted as the most suitable qualitative research design for the study. The data analysis in case study design focuses on one phenomenon which the researcher selects to understand in-depth regardless of the number of sites or participants for the study (Mcmillan \& Schumacher, 2006). This study aims to thoroughly and richly reveal the opinions of teachers about Open Course Materials. 


\section{Research Group}

The research is carried out on 12 math teachers with professional experience working at all two high schools in the Eastern Anatolia Region in Turkey.

\section{Data Collection}

In the research, Open Course Materials Interview Form (OCMIF) developed by the researchers was applied as a data collection tool. This is because the main data collection tool in the phenomenological research is the interview (Yıldırım \& Şimşek, 2013). While preparing the OCMIF, two academicians who are experts in qualitative research methods were consulted. In line with the suggestions of expert academicians in qualitative research methods, the logic and language errors in the form have been corrected and the order of the questions in the form has been changed. After these stages, OCMIF was finalized and applied to the participants. The interviewed teachers were selected voluntarily among teachers who could express themselves and who had easy accessibility. Before the interviews with the teachers, it was explained by the researchers that the study would be conducted according to the principle of volunteerism and the teachers who did not want to continue working could leave the study at any time. It is stated by the researchers that the names and information of the teachers will not be shared with anyone and the research results will use code names instead of their names $(\mathrm{T} 1, \mathrm{~T} 2, \mathrm{~T} 3, \ldots)$. Interviews with teachers took about 10 minutes. All of the interviews were conducted between the author and teachers in an environment where prospective teachers felt comfortable.

\section{Data Analysis}

The content analysis method is used for data analysis. The content analysis gives meaning to raw data, creates a certain framework and reveals codes and categories and concretizes the clarified subject (Patton, 2002). In the creation of codes and categories, the data was created primarily the codes and categories that could be encountered by the author. Afterward, codes and categories were created by examining them separately by two researchers experienced in mathematics education. As a result of the analysis, the researchers came together to compare the codes and categories, and the codes and categories with different opinions were finalized. Miles and Huberman (1994) call the similar codes as Consensus and the dissociated codes as Disagreement and propose Consensus Percentage $=$ Consensus $/($ Consensus + Disagreement $) * 100$ for coder reliability. In the study, the agreed percentage of the codes obtained by the researchers was found to be .83 . The Miles-Huberman reliability formula value being .70 and above shows that the coding is reliable (Yıldırım \& Şimşek, 2013). A participant's answer to a question was mostly put into only one category, but there were cases where the answer was put into multiple categories. Answers of students were frequently presented descriptively. By this means, it is aimed to improve the validity and reliability of the research.

\section{Findings}

The findings were analyzed by content analysis method to reveal the views of faculty members more clearly. Frequency tables are used for digitizing data. Frequency tables are presented in tables by converting them into percentage form. Quotations are made directly from the participants' views to give examples of the categories and codes that emerged when the findings were transmitted.

To find out what the teachers' open course materials mean, the question of "What is the meaning of the Open Course Materials for you with a teacher's eye?" is asked. It is determined that the answers obtained are collected under 11 categories. The categories and the responses of the teachers used in creation of these categories are given in Table 1.

Table 1: Teachers' Opinions about Open Course Materials

\begin{tabular}{|l|c|l|}
\hline \multicolumn{1}{|c|}{ Categories } & $\mathbf{\%}$ & \multicolumn{1}{c|}{ Opinions of Teachers } \\
\hline Free & 7 & T1: Free, educational materials in the electronic environment \\
\hline $\begin{array}{l}\text { Virtual Learning } \\
\text { Environment }\end{array}$ & 11 & $\begin{array}{l}\text { T10: Virtual learning environments where all kinds of learning deficiencies } \\
\text { can be solved. }\end{array}$ \\
\hline
\end{tabular}




\begin{tabular}{|c|c|c|}
\hline Easily accessible & 14 & $\begin{array}{l}\text { T3: Accessible, expresses all common course materials } \\
\text { T10: Depending on the technological development, it is a learning } \\
\text { environment where not only the students but the instructors, teachers, etc., } \\
\text { can reach and use them at any moment. }\end{array}$ \\
\hline $\begin{array}{l}\text { Open to anyone in an } \\
\text { electronic environment }\end{array}$ & 30 & $\begin{array}{l}\text { T8: Courses given in electronic environment. } \\
\text { T9: Applications such as video, presentation and animation are taken from } \\
\text { internet. }\end{array}$ \\
\hline Available in courses & 4 & T9: To use social media environment in lessons. \\
\hline Doesn't make sense & 4 & T12: No, it doesn't make any sense. \\
\hline $\begin{array}{l}\text { Provides more and more } \\
\text { detailed information to the } \\
\text { student }\end{array}$ & 7 & $\begin{array}{l}\text { T4: It provides me with professional facilities in order to provide more and } \\
\text { more detailed information to the student. }\end{array}$ \\
\hline $\begin{array}{l}\text { Provides Professional } \\
\text { Convenience }\end{array}$ & 4 & $\begin{array}{l}\text { T4: It provides me with professional facilities in order to provide more and } \\
\text { more detailed information to the student. }\end{array}$ \\
\hline $\begin{array}{l}\text { An area mostly applied by } \\
\text { people studying in open } \\
\text { education }\end{array}$ & 4 & $\begin{array}{l}\text { T6: It is an area that can benefit in formal education. However, it is an area } \\
\text { mostly applied by people who study in the field of "Open Education". }\end{array}$ \\
\hline $\begin{array}{l}\text { Its contribution to education } \\
\text { will be of great importance. }\end{array}$ & 11 & $\begin{array}{l}\text { T6: I'm thinking that the importance of it will be folded. } \\
\text { T11: The contents prepared by using computer technologies have become } \\
\text { widespread. In this respect, its contribution to education life cannot be denied. }\end{array}$ \\
\hline $\begin{array}{l}\text { Accelerate the step to } \\
\text { e-learning }\end{array}$ & 4 & T5: It is a tool that accelerates the step towards e-learning. \\
\hline Total & 100 & \\
\hline
\end{tabular}

Examining Table 1, teachers expressed that the most open course materials are open to everyone in the electronic environment. In other categories, they stated that open lecture materials should be easily accessible, contributed to education and education, and created a virtual learning environment. Apart from that, a teacher stated that he did not make any sense about the open course materials.
To get the opinions of the teachers about the online educations, shared files and questions that are popular on the internet, the question of "So what do you think about the training, shared files, documents and questions made over the internet?" is asked. It is determined that the answers obtained are collected under 14 categories. The categories and the responses of the teachers used in the creation of these categories are given in Table 2.

Table 2: Teachers' Opinions about Online Educations, Shared Files and Questions

\begin{tabular}{|l|c|l|}
\hline \multicolumn{1}{|c|}{ Categories } & $\%$ & \multicolumn{1}{c|}{ Opinions of Teachers } \\
\hline Grows as information is shared & 4 & $\begin{array}{l}\text { T1: I find such shares very useful with the principle that information } \\
\text { grows as they share. }\end{array}$ \\
\hline Very useful & 28 & $\begin{array}{l}\text { T7: Although there are shortcomings, I usually find it useful and } \\
\text { understandable. } \\
\text { T3: Learning is permanent when presented both visually and auditory. I } \\
\text { find it very useful. }\end{array}$ \\
\hline Need to be improved & 4 & $\begin{array}{l}\text { T2: In particular, I think that the sharing of official institutions and } \\
\text { animations should be developed. }\end{array}$ \\
\hline $\begin{array}{l}\text { Inadequate and unsupervised } \\
\text { resources are damaging }\end{array}$ & 12 & $\begin{array}{l}\text { T2: I think that inadequate and unsupervised publications do not benefit, } \\
\text { but rather harm. }\end{array}$ \\
\hline Effective learning & 8 & $\begin{array}{l}\text { T10: Sharing the correct information from the required sources of } \\
\text { documents shared on the Internet, etc. can provide effective learning. }\end{array}$ \\
\hline
\end{tabular}




\begin{tabular}{|l|r|l|}
\hline Online educations are not helpful & 4 & T9: I think online educaitons on the internet are not useful. \\
\hline $\begin{array}{l}\text { It needs to be kept under } \\
\text { surveillance }\end{array}$ & 4 & T12: More control is required. \\
\hline Mostly advertising & 4 & T12: Publications with mostly advertisements \\
\hline $\begin{array}{l}\text { Unnecessary, level of } \\
\text { extracurricular activities available }\end{array}$ & 4 & $\begin{array}{l}\text { T11: Unnecessary, hollow, out-of-level activities force the student and } \\
\text { the teacher. }\end{array}$ \\
\hline Provides equal opportunity & 4 & $\begin{array}{l}\text { T3: The availability of resources and cheaper in terms of cost provides } \\
\text { equality of opportunity in education. }\end{array}$ \\
\hline Low cost & 12 & $\begin{array}{l}\text { T5: It is a free and educational electronic environment designed for } \\
\text { instructors, students and all those aiming at life-long learning. }\end{array}$ \\
\hline $\begin{array}{l}\text { Complex } \\
\text { Incorrectly redirects if not used } \\
\text { consciously }\end{array}$ & 4 & $\begin{array}{l}\text { T8: The documents shared on the Internet are extremely complicated } \\
\text { for someone who doesn't know the subject because it is not random and } \\
\text { organized. }\end{array}$ \\
\hline $\begin{array}{l}\text { Deficient because student is not } \\
\text { active }\end{array}$ & 4 & $\begin{array}{l}\text { T6: I can say that the student is lacking actively because she/he is not in } \\
\text { the process of education. }\end{array}$ \\
\hline Total & 100 & the wrong areas. \\
\hline
\end{tabular}

Examining Table 2, Teachers think that shared files, documents, questions and online education are very useful. On the other hand, teachers expressed the low cost of various resources shared on the internet. Teachers also expressed the opinion that those not insufficient and uncontrolled for such sharing would be unhelpful.
To determine for what purpose and how often teachers use open course materials, the question of "For what purpose and how often do you use open course materials?" is asked. It is determined that the answers obtained are collected under 9 categories. The categories and the responses of the teachers used in creation of these categories are given in Table 3.

Table 3: Teachers' Opinions about What Purpose and How Often they Use Open Course Materials

\begin{tabular}{|c|c|c|}
\hline Categories & $\%$ & Opinions of Teachers \\
\hline Information purposes - Always & 24 & $\begin{array}{l}\text { T1:I use it very often. Any information I would like to remember } \\
\text { about my field }\end{array}$ \\
\hline $\begin{array}{l}\text { For questions asked in the } \\
\text { exams - Very rare }\end{array}$ & 8 & $\begin{array}{l}\text { T2:I rarely use it. Sometimes I use the questions and solutions } \\
\text { about the subject. }\end{array}$ \\
\hline $\begin{array}{l}\text { For different viewing angles - } \\
\text { Usually }\end{array}$ & 8 & $\begin{array}{l}\text { T10:When I feel the lack of a professional issue, I usually use it to } \\
\text { see a different point of view and to reach the necessary information } \\
\text { in a situation where I don't have my resources. }\end{array}$ \\
\hline In the course - Always & 8 & T9:I use video, presentation and animations in my lessons. \\
\hline In the course - Sometimes & 8 & T12:I sometimes use it as visual and written material in lessons. \\
\hline In the Exams - Usually & 8 & T12:I usually use it in exams. \\
\hline Reinforce purposes -Always & 14 & $\begin{array}{l}\text { T11:I use almost every course to consolidate the course content, to } \\
\text { improve the intelligibility of achievements and to adapt the student } \\
\text { to the next educational environment. }\end{array}$ \\
\hline $\begin{array}{l}\text { For support and training courses } \\
\text { - Weekly }\end{array}$ & 8 & $\begin{array}{l}\text { T3:I use it weekly. In particular, I use the tests published on the } \\
\text { ODSGM as part of the support training course. }\end{array}$ \\
\hline $\begin{array}{l}\text { Information purposes - } \\
\text { Sometimes }\end{array}$ & 14 & T7:I use occasionally in order to reach information. \\
\hline Total & 100 & \\
\hline
\end{tabular}


Examining Table 3, it is seen teachers generally benefit from open course materials. According to the prominent categories, it is seen that teachers usually use the course materials for information purposes at all times or sometimes \& for reinforcement purposes.

\section{Discussion, Conclusion and Suggestions}

The aim of this study is to determine whether math teachers have an idea about the open course materials and to get their opinions about the use of open course materials.

The views were analyzed in the findings section. According to the analysis, it was seen that the teachers had information about the open course materials. According to the opinions given for the first question, teachers expressed that the most open course materials are open to everyone in the electronic environment. In other categories, they stated that open lecture materials should be easily accessible, contributed to education and education, and created a virtual learning environment. Apart from that, a teacher stated that he did not make any sense about the open course materials. The most important purpose in creating the Open Course Materials is to present the course systems in the educational institutions open to the public in an electronic environment. The findings of the study can be said to be parallel to this result (Kubuş, et al., 2008; OEC, 2018; MIT, 2002).

Considering the opinions given for the second question, teachers think that shared files, documents, questions and online education are very useful. On the other hand, teachers expressed the low cost of various resources shared on the internet. Teachers also expressed the opinion that those not insufficient and uncontrolled for such sharing would be unhelpful. In the study conducted by Mazlum (2018), the importance of lifelong learning has increased. It is stated that open course materials are an important tool for easy access to quality information sources. In this study, it was observed that teachers stated parallel views. In addition, the teachers stated that there are some situations in which open lesson materials are not used in our country. For example, lack of control, inappropriate content, and so on. As. This result is fully consistent with the results of the study by Al and Madran (2013).
Considering the opinions given for the third question, teachers generally benefit from open course materials. According to the prominent categories, it is seen that teachers usually use the course materials for information purposes at all times or sometimes and for reinforcement purposes. These opinions of the teachers stated that Kubuş, et al., (2008), in the final part of the study; made available to everyone in the electronic environment so that everyone can benefit from some of the courses given in MIT, both teachers and students can learn the different methods that can used in their courses are parallel with results.

According to the results of the study, a few suggestions can be given:

- Introductory and informative meetings should be held for the teachers.

- Conscious internet use should be a course.

- Teachers should develop activities that they can share publicly and teachers should be encouraged.

\section{References}

Al, Umut, and Orçun Madran. "An Overview to Open Courseware: An Example of the Turkish Academy of Sciences." Bilgi Dünyası, vol. 14, no. 1, 2013, pp. 1-16.

Eker, Zeynep. "Open Course." http://yunus. hacettepe.edu.tr/ zeynep.eker12/webfinal/

Johansen, Justin, and David Wiley. "A Sustainable Model for OpenCourseWare Development." Educational Technology Research and Development, vol. 59, 2010.

Johnstone, Sally M., and Russell Poulin. "What is OpenCourseWare and Why Does It Matter?" Change, vol. 34, no. 4, 2002, pp. 48-50.

Kubuş, O., et al. "METU OpenCourseWare Project." ICITS, 2008.

Mazlum, Fehmi Soner. "An Experimental Investigation into Internet OpenCourseWares in Line with the Academic Achievement of Higher Education Students." Sanat Eğitimi Dergisi, vol. 6, no. 1, 2018, pp. 83-95.

Mcmillan, James H., and Sally Schumacher. Research in Education: A Conceptual Introduction. Longman, 2006.

Miles, Matthew B., and A. Michael Huberman. An Expanded Sourcebook: Qualitative Data Analysis. Sage Publications, 1994. 
Özkul, Ali Ekrem. "Açık Eğitim Kaynakları Yazıcı, A., et al. "OpenCourseWare Initiative in Girişimi ve Ulusal Açık Ders Malzemeleri Konsorsiyumu." XII. "Türkiye'de Internet" Konferanst, 2007, pp. 168-174.

Turkey." Future e-Learning Conference, 2008, pp. 489-494.

Patton, Michael Quinn. Qualitative Research \& Evaluation Methods. Sage Publications, 2002.

"Site Statistics." MITOpenCourseWare, http://ocw. mit.edu/about/site-statistics

Year End Review 2017. Open Education Concortium (OEC), 2018, https://www.oeconsortium. org/wp-content/uploads/2018/02/year-endreview-2017.jpg

Towards Knowledge Societies: UNESCO World Yıldırım, Ali, and Hasan Şimşek. Sosyal Bilimlerde Report. UNESCO, 2005. Nitel Araştırma Yöntemleri. Seçkin Publishing, 2013.

TUBA Open Course Materials Project 2006-2011. Turkish Academy of Sciences, 2011.

\section{Author Details}

Furkan Ozdemir, Research Assistant, Department of Mathematics Education, Faculty of Education, Siirt University, Siirt, Turkey, Email ID: furkanozdemir24@gmail.com 